\title{
Quinolizidines alkaloids: Petrosin and xestospongins from the sponge Oceanapia sp.
}

\author{
KEISHAM SARJIT SINGH ${ }^{\mathrm{a}, *}$, BABULAL DAS $^{\mathrm{b}}$ and CHANDRAKANT G NAIK ${ }^{\mathrm{a}}$ \\ ${ }^{a}$ Bioorganic Chemistry Laboratory, National Institute of Oceanography (CSIR), Goa 403 004, India \\ ${ }^{\mathrm{b}}$ Department of Chemistry, Indian Institute of Technology (IIT), Guwahati 781 039, India \\ e-mail: keisham@nio.org
}

MS received 10 May 2010; revised 27 April 2011; accepted 13 June 2011

\begin{abstract}
A bisquinolizidine alkaloid, petrosin (1) and a series of bis-1-oxaquinolizidine, xestospongins (2-9), were obtained from the ethyl acetate extract of the sponge Oceanapia sp. Petrosin was obtained along with xestospongin- C, D, E, F, G, H, I and J having di-hetroatom rings, from the ethyl acetate extract of the sponge. The compounds exhibited moderate to high activities against some microorganisms and clinical isolates. The structures of the alkaloids were elucidated by NMR and ESIMS spectroscopic data. The structure of petrosin was confirmed by an X-ray diffraction study.
\end{abstract}

Keywords. Alkaloid; bisquinolizidine; Oceanapia; sponge; crystallography.

\section{Introduction}

Current interest in marine natural products arises owing to rich in secondary metabolites in marine organisms and larger biodiversity of ocean than in the terrestrial counterpart. Indeed, several secondary metabolites have been reported from marine invertebrates, microbes and their biological activities were investigated. ${ }^{1-3}$ Recently, brominated acetylenic acids isolated from the marine sponges of genera Xestospongia and Oceanapia were reported to possess antibacterial, ${ }^{4}$ antifungal ${ }^{5}$ and HIV protease inhibitory ${ }^{6}$ activities. Sugar derivatives such as rhizochalin, ${ }^{7}$ oceanalin ${ }^{8}$ and bifunctional sphingolipids ${ }^{9}$ were also reported from the marine sponge belonging to the genus Oceanapia. During the course of our investigation on bioactive metabolites from marine organisms, ${ }^{10}$ we found petrosin and a series of bis1-oxaquinolizidines alkaloid viz., xestospongins from the sponge Oceanapia sp. Previous workers have isolated petrosin ${ }^{11}$ and xestospongin ${ }^{12}$ from other sources and shown to possess anti-HIV ${ }^{13}$ and ichthyotoxicity properties. ${ }^{14}$

It is noteworthy that alkaloids reported from Oceanapia sp. are mainly peridoacridin, ${ }^{15}$ a few reports are available on alkaloids such as peridosamine, ${ }^{16}$ isoquinoline glycosides, ${ }^{8}$ bromotyrosin ${ }^{17}$ and oceanapamine ${ }^{18}$ However, to the best of our knowledge alka-

*For correspondence loids having a bisquinolizidine ring have not been reported from the Oceanapia sp. As a part of our study on bioactive metabolites from marine organisms, ${ }^{10}$ herein, we wish to report the structural elucidation three new (6, 7 and 9) and six known alkaloids (1-5 and 8) from the sponge Oceanapia sp. We have also investigated the antimicrobial properties of the compounds against some microorganisms and clinical isolates. The structures of the compounds were established on the basis of NMR and ESIMS spectroscopic data. The solid state structure of petrosin was determined by X-ray crystallography.

\section{Experimental}

\subsection{General experimental procedures}

Infrared spectra were obtained in a diffused reflection spectroscopy (DRS) assembly on a Shimadzu8201PC spectrometer with sample prepared in $\mathrm{KBr}$. ${ }^{1} \mathrm{H}$ and ${ }^{13} \mathrm{C}$ NMR spectra were recorded on a BrukerAvance $300 \mathrm{MHz}$ spectrometer at $300.13 \mathrm{MHz}$ for ${ }^{1} \mathrm{H}$ and $75.47 \mathrm{MHz}$ for ${ }^{13} \mathrm{C}$, in $\mathrm{CDCl}_{3}$ with $\mathrm{SiMe}_{4}$ as internal reference and coupling constants are given in Hertz. ESIMS data were performed on QTOP (MS/MS) Applied Biosystem mass spectrometer. Column chromatography was performed on silica gel (230-400 mesh or $60-120$ mesh, Merck, Darmstadt, Germany or SRL, Pvt. Ltd, India) or Shephadex LH-20. 


\subsection{Animal materials}

Specimens of Oceanapia sponge were collected by hand by divers equipped with SCUBA off the coast of southern coast of India at a depth of 5-15 m. Freshly collected sponge specimens were kept in the fridge till work-up. Reference voucher have been deposited at the National Institute of Oceanography, Goa, under the voucher no. NIO-837.

\subsection{Extraction and isolation}

Dried and minced specimens of Oceanapia (dry weight $120 \mathrm{~g}$, dried using lyophilizer) were extracted subsequently with petroleum ether, ethyl acetate and $n$ butanol. The ethyl acetate fraction was subjected to flash column chromatography over silica gel mesh 230-400. Ethyl acetate: Petroleum ether (v/v) solvent system was used as eluant with increasing polarity $(0: 100$ to $100: 0 \mathrm{v} / \mathrm{v})$ and finally $200 \mathrm{ml}$ of methanol to remove polar compounds from the column. This leads to collection of fractions 1-52. Fractions 30-32 on re-crystallization with chloroform/methanol gave colourless rectangular crystals of compound $\mathbf{1}(30 \mathrm{mg})$.

\section{Compound 1 (Petrosin).}

FTIR (KBr, cm ${ }^{-1}$ ): 2927, 17101456.

${ }^{1}$ HNMR: $0.634\left(\mathrm{q}, 2 \mathrm{H}, J_{H-H}=9.6\right), 0.78(\mathrm{q}, 2 \mathrm{H}$, $\left.J_{H-H}=12.6\right), 0.96\left(\mathrm{~d}, 6 \mathrm{H}, J_{H-H}=6.3\right), 1.10(\mathrm{~m}$, 2H), 1.26-1.68 (br, 20H), 1.96 (br, 4H), 2.55 (m, $4 \mathrm{H})$, $2.95(\mathrm{~m}, 10 \mathrm{H})$.

${ }^{13} \mathrm{CNMR}: 1.16\left(\mathrm{~s}, \mathrm{CH}_{3}\right), 23.76\left(\mathrm{~s}, \mathrm{CH}_{2}\right), 24.05$ (s, $\mathrm{CH}_{2}$ ), 24.17 (s, $\left.\mathrm{CH}_{2}\right), 24.84$ (s, $\left.\mathrm{CH}_{2}\right), 27.28\left(\mathrm{~s}, \mathrm{CH}_{2}\right)$, $28.71\left(\mathrm{~s}, \mathrm{CH}_{2}\right), 29.28\left(\mathrm{~s}, \mathrm{CH}_{2}\right), 36.83(\mathrm{~s}, \mathrm{CH}), 40.28$ (s, $\mathrm{CH}), 51.70(\mathrm{~s}, \mathrm{CH}), 56.02\left(\mathrm{~s}, \mathrm{CH}_{2}\right), 64.59\left(\mathrm{~s}, \mathrm{CH}_{2}\right)$, 70.35 (s, $\mathrm{CH}), 213.80(\mathrm{~s}, \mathrm{C}=\mathrm{O})$.

ESIMS: $\mathrm{m} / \mathrm{z} 471.4889[\mathrm{M}+\mathrm{H}]^{+}$(calculated for $\left.\mathrm{C}_{30} \mathrm{H}_{51} \mathrm{~N}_{2} \mathrm{O}_{2}, 471.3950\right), \mathrm{m} / \mathrm{z}[\mathrm{M} / 2+\mathrm{H}]^{+} 236.2829$.

Isolation of $\mathbf{2}$ and 3: Compounds $\mathbf{2}$ and $\mathbf{3}$ were obtained by repeated chromatography of fractions 38 44 over silica gel column using $\mathrm{CHCl}_{3} / \mathrm{MeOH}$ as eluant. This resulted in isolation of a light yellow solid containing a mixture of compounds $\mathbf{2 - 6}$, which after separation over sephadex LH-20 yielded the pure compounds 2 and $\mathbf{3}$ along with a mixture of compounds 4-6. Fractions 35-37 on concentration under reduced pressure gave a viscous liquid which changed into light yellow solid when refrigerated contained a mixture of compounds 7-9.

\subsection{Spectroscopic data}

2.4a Compound 2 (Xestospongin- $C$ ): FTIR (KBr, $\left.\mathrm{cm}^{-1}\right)$ : 2927, 2850, 1438.

${ }^{1}$ HNMR: 4.38 (s, H-10), 3.57 (br t, $J=12.6, \mathrm{H}-2$ ), 3.36 (br t, $J=10.8 \mathrm{~Hz}, \mathrm{H}-2^{\prime}$ ), 3.11 (br d, H-10', $J=$ 7.7), 3.09 (br d, $J=10.5, \mathrm{H}-4, \mathrm{H}-6^{\prime} \alpha$ ), 2.95 (br d, $J=10.7, \mathrm{H}-4,2 \times 4^{\prime}$ ), 2.77 (br t, H-6 $J=16.8$ ) 2.50 (br d, H-4), 2.17 (br t, $J=23.3, \mathrm{H}-6^{\prime} \beta$ ), 1.93 (br t, H-6 $\beta$ ), 1.69-1.17 (m, $18 \times \mathrm{CH}_{2}, \mathrm{H}-9$ and H-9').

${ }^{13}$ C NMR: 95.83 (d, C-10'), 87.47 (C-10), 75.99 (C2), $75.35\left(\mathrm{C}-2^{\prime}\right), 54.12\left(\mathrm{C}-4^{\prime}\right), 53.93\left(\mathrm{C}-6^{\prime}\right), 52.09(\mathrm{C}-$ 4), 45.02 (C-6), 40.39 (C-9'), 39.74 (C-9), 35.71, 35.50, $32.03,31.56,31.50,31.45,31.15,31.07,29.61,29.26$, 28.84, 28.77, 25.97, 25.89, 25.11 (d), 24.89, 24.68.

ESIMS: $m / z \quad 447.3458[\mathrm{M}+\mathrm{H}]^{+}$(calculated for $\left.\mathrm{C}_{28} \mathrm{H}_{51} \mathrm{~N}_{2} \mathrm{O}_{2}, \quad 447.3950\right), m / z \quad 224.1390 \quad[\mathrm{M} / 2+\mathrm{H}]^{+}$ (223).

2.4b Compound 3 (Xestospongin-D): ${ }^{1}$ HNMR: 4.59 (s, H-10), 3.94 (br t, $J=10.3, \mathrm{H}-2$ ), 3.52 (br t, $J=$ $10.5, \mathrm{H}-2^{\prime}$ ), 3.32 (br d, $\left.J=6, \mathrm{H}-6^{\prime} \alpha\right), 3.07$ (br d, $J=$ $\left.11.1,2 \times{ }^{\prime}-4^{\prime}, \mathrm{H}-10^{\prime}\right), 2.79$ (br d, $J=11.1, \mathrm{H}-6 \alpha$ ), 2.25 (br d, $J=10.8, \mathrm{H}-4$ ), 2.17 (br t, $J=8.7, \mathrm{H}-6^{\prime} \beta$ ), 1.98 (br t, $J=8.7, \mathrm{H}-6 \beta$ ), $1.69-1.17$ (m, $18 \times \mathrm{CH}_{2}$ and $\mathrm{H}_{-} \mathrm{9}^{\prime}$ ).

${ }^{13}$ C NMR: 95.87 (d, C-10'), 90.27 (C-10), 77.21 (C2), 75.91 (C-2'), 70.14 (C-9), 54.05 (C-4'), 53.93 (C$\left.6^{\prime}\right), 52.48$ (C-4), 45.09 (C-6), 40.29 (C-9'), 39.42, 34.51, $34.26,32.35,31.86,31.77,30.35,30.26,30.05,29.68$, $29.15,28.76,28.63,26.68,25.69,25.22,25.06,24.58$, 22.26, 18.20 .

ESIMS: $m / z$ 463.2311 $[\mathrm{M}+1]^{+}$(calculated for $\left.\mathrm{C}_{28} \mathrm{H}_{51} \mathrm{~N}_{2} \mathrm{O}_{3}, 463.3899\right)$, 445.2782 (M- $\left.\mathrm{H}_{2} \mathrm{O}+1\right)(18)$.

\subsection{Mass analysis data of compounds 4-9}

2.5a Compound 4 (Xestospongin- $E$ ): $\quad m / z 479.2505$ $[\mathrm{M}+1]^{+}$(calculated for $\mathrm{C}_{28} \mathrm{H}_{51} \mathrm{~N}_{2} \mathrm{O}_{4}, 479.3848$ ); $461.2703\left[\mathrm{M}-\mathrm{H}_{2} \mathrm{O}+1\right]^{+}(18), 443.2659\left[\mathrm{M}-2 \mathrm{H}_{2} \mathrm{O}+1\right]^{+}$ (36), $222.1018\left[\mathrm{M}-2 \mathrm{H}_{2} \mathrm{O} / 2+1\right]^{+}(221)$.

$2.5 \mathrm{~b}$ Compound 5 (Xestospongin- $F$ ): $\quad$ ESI-MS $m / z$ $495.2682[\mathrm{M}+1]^{+}$(calculated for $\mathrm{C}_{28} \mathrm{H}_{51} \mathrm{~N}_{2} \mathrm{O}_{5}$, 495.3797).

2.5c Compound 6 (Xestospongin- $G$ ): $\quad$ ESI-MS $m / z$ $511.2176[\mathrm{M}+\mathrm{H}]^{+}$(calculated for $\mathrm{C}_{28} \mathrm{H}_{51} \mathrm{~N}_{2} \mathrm{O}_{6}$, 511.3747). 


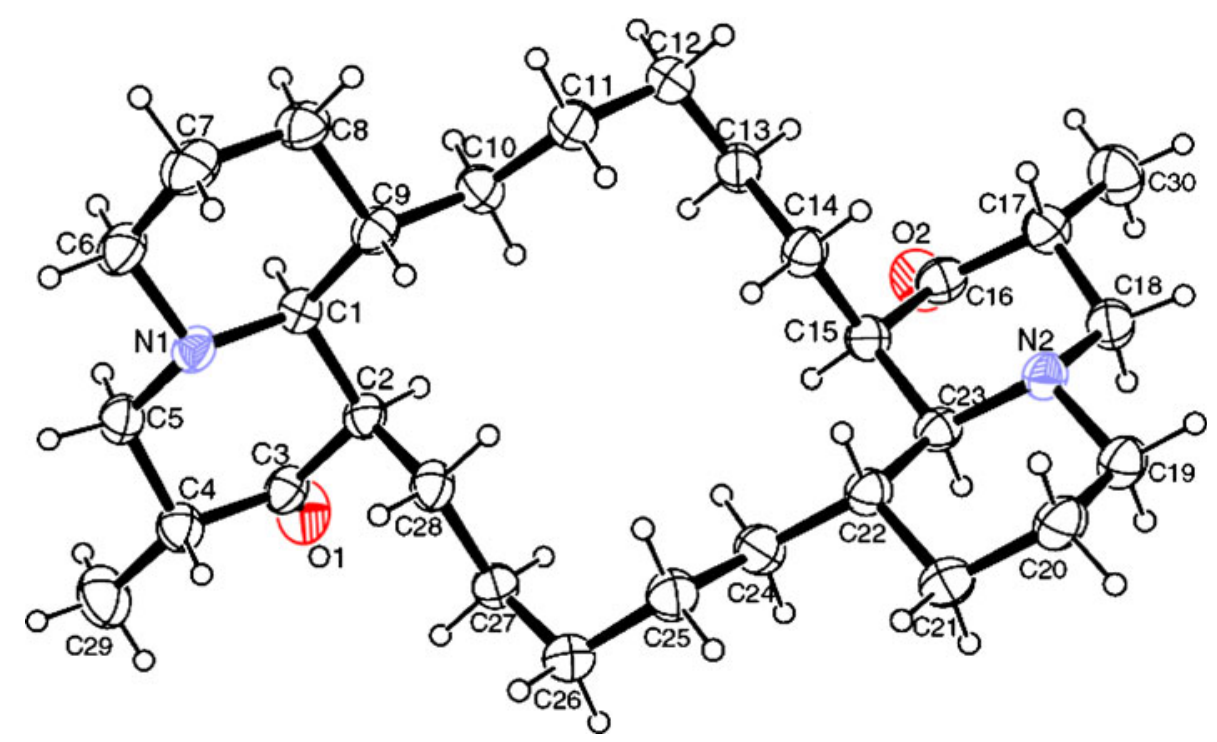

Figure 1. ORTEP diagram of $\mathbf{1}$ with atoms numbering scheme.

2.5d Compound 7 (Xestospongin-H): ESI-MS $\mathrm{m} / \mathrm{z}$ $461.2524[\mathrm{M}+\mathrm{H}]^{+}$(calculated for $\mathrm{C}_{29} \mathrm{H}_{53} \mathrm{~N}_{2} \mathrm{O}_{2}$, 461.4107).

2.5e Compound 8 (Xestospongin-I): ESI-MS, $\mathrm{m} / \mathrm{z} 477.2544[\mathrm{M}+\mathrm{H}]^{+}$(calculated for $\mathrm{C}_{29} \mathrm{H}_{53} \mathrm{~N}_{2} \mathrm{O}_{3}$, 477.4056); $459.2192 \quad\left[\mathrm{M}-\mathrm{H}_{2} \mathrm{O}\right]^{+}$(18), 224.1162, 238.1248 .

2.5f Compound 9 (Xestospongin-J): ESI-MS: $m / z$ $493.2458[\mathrm{M}+\mathrm{H}]^{+}$(calculated for $\mathrm{C}_{29} \mathrm{H}_{53} \mathrm{~N}_{2} \mathrm{O}_{4}$, 493.4005); $475.2083 \quad\left[\mathrm{M}-\mathrm{H}_{2} \mathrm{O}\right]^{+} \quad(18), 457.1984$ $\left[\mathrm{M}-2 \mathrm{H}_{2} \mathrm{O}\right]^{+}(36), 220.1242,236.1162$.

\subsection{Antimicrobial assays}

Antimicrobial properties of the compounds were tested employing the Disk diffusion technique. ${ }^{19}$ Antifungal assay was carried out against the fungus Aspergillus funigatus, Rhodotorula, Candida albicans and Aspergillus niger whereas Vibrio cholera,

Table 1. Bond lengths $(\AA)$ and angles $\left(^{\circ}\right)$.

\begin{tabular}{lccc}
\hline $\begin{array}{l}\text { Bond lengths } \\
\text { C23-N2 }\end{array}$ & $1.484(2)$ & C1-N1 & $1.477(2)$ \\
C3-O1 & $1.213(2)$ & C16-O2 & $1.219(2)$ \\
C18-N2 & $1.451(2)$ & C6-N1 & $1.474(2)$ \\
C19-N2 & $1.470(2)$ & C5-N1 & $1.459(3)$ \\
Bond angles & & & \\
C18-N2-C19 & $107.65(15)$ & C5-N1-C6 & $108.08(16)$ \\
C21-C22-C24 & $111.05(17)$ & C2-C1-C9 & $112.74(16)$ \\
C15-C23-C22 & $113.56(15)$ & C3-C2-C28 & $110.86(17)$ \\
\hline
\end{tabular}

Escherichia coli and Staphylococcus aureus were employed in the antibacterial assay. A 50-200 $\mu \mathrm{g}$ portion of the compounds were applied onto pre-sterilised disc. The disc was placed on agar plates that had been seeded with respective organisms. Diameters of inhibitory zones were measured after the plates were incubated at $28^{\circ} \mathrm{C}$ for $24-48 \mathrm{~h}$.

\section{$2.7 X$-ray crystallography studies}

The X-ray intensity data were collected on a Bruker Nonius SMART CCD area detector at $296(2)^{\circ} \mathrm{K}$ using $\mathrm{M}_{0}-\mathrm{K}_{\alpha}$ radiation $(\lambda=0.71073 \AA$ ) equipped with graphite monochromater. Intensity data were corrected for Lorentz and polarization effects and absorption correction was made using SAINT program. ${ }^{20}$ The structures were solved by direct methods (SHELXS-97) ${ }^{21}$ and refined by full matrix least squares base on $\mathrm{F}^{2}$ using (SHELXL-97). ${ }^{22}$ Non-hydrogen atoms were refined anisotropically and hydrogen atoms were refined using a 'riding' model. Refinement converged at a final $\mathrm{R}=$ 0.0608 and $\mathrm{wR}_{2}=0.1279$ for unique data $\mathrm{F}^{2}$ ). ORTEP diagram $^{23}$ of the compound is shown in figure 1. Selected bond lengths and angles are listed in table 1. Summary of crystal structure determination and refinement are presented in table 2.

\section{Results and discussion}

\subsection{Structure elucidation of the compounds}

The ethyl acetate extract of sponges of the genus Oceanapia, collected from the southern coast of India, 
Table 2. Summary of structure determination and refinement for compound $\mathbf{1}$.

\begin{tabular}{ll}
\hline Empirical formula & $\mathrm{C}_{30} \mathrm{H}_{50} \mathrm{~N}_{2} \mathrm{O}_{2}$ \\
Formula weight & 470.72 \\
Temperature $(\mathrm{K})$ & $296(2)$ \\
Wavelength $(\AA)$ & 0.71073 \\
Crystal system & Monoclinic \\
Space group & $\mathrm{P} 2(1) / \mathrm{c}$ \\
Unit cell dimensions & \\
a $(\AA)$ & $9.9989(12)$ \\
$\mathrm{b}(\AA)$ & $15.8599(12)$ \\
$\mathrm{c}(\AA)$ & $17.8402(16)$ \\
$\beta\left(^{\circ}\right)$ & $90.392(4)$ \\
Volume $\left(\AA^{3}\right)$ & $2829.1(5)$ \\
$\mathrm{Z}$ & 4 \\
Density (calculated) $\mathrm{Mg} / \mathrm{m}^{3}$ & 1.105 \\
$\mathrm{~F}(000)$ & 1040 \\
Crystal size (mm ${ }^{3)}$ & $0.45 \times 0.28 \times 0.16 \mathrm{~mm}^{3}$ \\
Theta range for data collection $\left(^{\circ}\right)$ & 1.72 to 28.25 \\
Index ranges & $-13 \leq \mathrm{h} \leq 11,-20 \leq \mathrm{k} \leq 20,-23 \leq 1 \leq 22$ \\
Reflections collected & 28970 \\
Independent reflections & $6255[\mathrm{R}(\mathrm{int})=0.0556]$ \\
Completeness to theta $\left({ }^{\circ}, \%\right)$ & $28.25,95.4$ \\
Absorption correction & None \\
Refinement method & Full-matrix least-squares on $\mathrm{F}^{2}$ \\
Data/restraints/parameters & $6255 / 0 / 309$ \\
Goodness-of-fit on $\mathrm{F}^{2}$ & $6255 / 0 / 309$ \\
Final R indices $[\mathrm{I}>2$ sigma(I)] & $\mathrm{R}_{1}=0.0608, \mathrm{wR}_{2}=0.1279$ \\
$\mathrm{R}$ indices (all data) & $\mathrm{R}_{1}=0.1284, \mathrm{wR}_{2}=0.1524$ \\
Largest diff. peak and hole & 0.160 and $-0.151 \mathrm{e} . \AA^{-3}$ \\
\hline
\end{tabular}

upon chromatography yielded two types of alkaloids having a bisquinolizidine ring, namely petrosin (1) and a series of alkaloids containing 1-oxa-bisquinolizidine ring, xestospongin $\mathrm{C}(\mathbf{2}), \mathrm{D}(\mathbf{3}), \mathrm{E}(\mathbf{4}), \mathrm{F}(\mathbf{5}), \mathrm{G}(\mathbf{6})$, $\mathrm{H}(\mathbf{7}), \mathrm{I}(\mathbf{8})$ and J (9) (scheme 1).

Compound $\mathbf{1}$ was separated as colourless crystals from the ethyl acetate extract by column chromatography, followed by crystallization from $\mathrm{CHCl}_{3}: \mathrm{MeOH}$, while several xestospongin alkaloids were obtained as a mixture from this same extract. Compound 1 shows IR absorption bands at $2929 \mathrm{~cm}^{-1}$ assignable to Bohlmann bands ${ }^{24}$ and $1710 \mathrm{~cm}^{-1}$ due to $\nu \mathrm{C}=\mathrm{O}$ group. Presence of $\mathrm{C}=\mathrm{O}$ group was further supported by the appearance of signal at $\delta 213$ in ${ }^{13} \mathrm{C}$ NMR spectrum. Molecular formula of $\mathbf{1}$ was deduced as $\mathrm{C}_{30} \mathrm{H}_{50} \mathrm{~N}_{2} \mathrm{O}_{2}$ based on ${ }^{13} \mathrm{C}$ NMR and ESI-MS data analysis. The presence of two methylene and one methine adjacent to heteroatom nitrogen was confirmed by the appearance of signal at $\delta 70.35\left(\mathrm{CH}_{2}\right), 64.59(\mathrm{CH}), 56.02\left(\mathrm{CH}_{2}\right)$ in the ${ }^{13} \mathrm{C}$ NMR spectrum. These values are in accordance with the reported values. ${ }^{11}$ The mass spectrum of the compound showed three distinct peaks at $\mathrm{m} / \mathrm{z} 471.4889$ $[\mathrm{M}+\mathrm{H}]^{+}, 493.5385[\mathrm{M}+\mathrm{Na}]^{+}$and $509.5316[\mathrm{M}+\mathrm{K}]^{+}$.
The dimeric nature of petrosin was confirmed by the appearance of only fifteen peaks in the ${ }^{13} \mathrm{C}$ NMR spectrum against the actual $\mathrm{C}_{30}$ skeleton. This is further supported by mass analysis data which showed peak at $m / z 236.2829$ corresponding to $[\mathrm{M} / 2+\mathrm{H}]^{+}$. The spectroscopic data of 1 suggest that the compound could be petrosin and data are in accordance with the reported values. ${ }^{11}$ The solid state structure of $\mathbf{1}$ was finally established by a single crystal X-ray analysis and the chiral centres were assigned as $\left(1 \mathrm{~S}^{*}, 2 \mathrm{R}^{*}, 4 \mathrm{R}^{*}, 9 \mathrm{~S}^{*}, 15 \mathrm{R}^{*}\right.$, $\left.17 \mathrm{R}^{*}, 22 \mathrm{~S}^{*}, 23 \mathrm{~S}^{*}\right)$.

Notably, it has been reported that petrosin may exist as six possible stereoisomers, which differ only by configuration at the junctions of the quinolizidines with the sixteen-membered ring. Molecular calculation showed that petrosin is the most stable isomer among the six possible stereoisomers viz., petrosin, petrosin- $\mathrm{A}$, petrosin- $\mathrm{B}$, petrosin- $\mathrm{B}^{\prime}$, petrosin-C, and petrosin-D. ${ }^{25}$

A series of closely related 1-oxaquinolizidine alkaloids (2-9) having di-hetero atom rings were also obtained from the ethyl acetate extract of the same sponge. They have been identified as xestospongin alkaloids by extensive NMR, mass spectral data analyses 


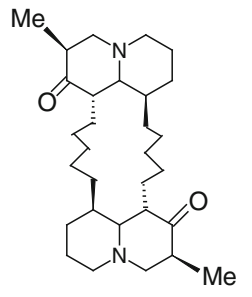

Petrosin (1)

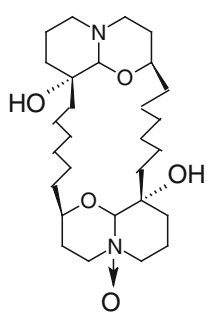

xestospongin $\mathrm{F}(\mathbf{5})$

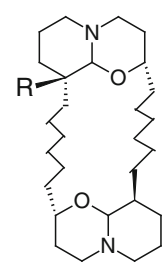

$\mathrm{R}=\mathrm{H}$; xestospongin $\mathrm{C}(2)$

$\mathrm{R}=\mathrm{OH}$; xestospongin $\mathrm{D}(\mathbf{3})$

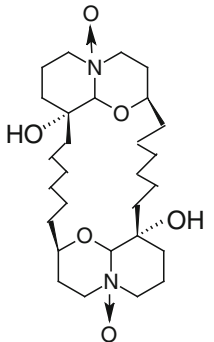

xestospongin $\mathrm{G}(6)$

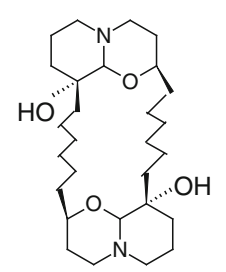

xestospongin $\mathrm{E}(4)$

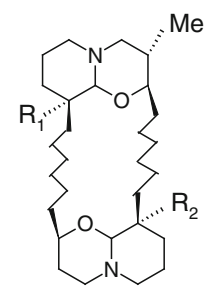

$\mathrm{R}_{1}=\mathrm{R}_{2}=\mathrm{H}$; xestopongin $\mathrm{H}$ (7)

$\mathrm{R}_{1}=\mathrm{H}, \mathrm{R}_{2}=\mathrm{OH}$; xestospongin I (8)

$\mathrm{R}_{1}=\mathrm{R}_{2}=\mathrm{OH}$; xestospongin $\mathrm{J}(\mathbf{9})$

Scheme 1. Chemical structure of compounds.

and comparison of their spectroscopic data with those of related compounds $\left({ }^{1} \mathrm{H},{ }^{13} \mathrm{C}\right.$ and mass spectra for selected compounds is available as supplementary materials). Mass spectral data of the xestospongin containing fraction revealed the presence of at least eight closely related compounds. Among the eight xestospongin alkaloids identified, only xestosponginC (2) and xestospongin-D (3) could be isolated in pure form by chromatography. However, attempt to isolate the other alkaloids in their pure state by chromatography was unsuccessful and as they are found in minor quantity. They were mainly identified by comparison of their ${ }^{13} \mathrm{CNMR}$ and mass data with related compounds. Isolation of xestospongin I (8), C (2) and D (3) from different sources have been reported $^{12}$ and a synthesis of petrosin and some of xestospongin alkaloids was described recently. ${ }^{25}$ The proton NMR spectrum of $\mathbf{2}$ displayed a singlet at $\delta$ 4.38 assignable to $\mathrm{CH}$ proton of the heterocyclic ring. The ${ }^{13} \mathrm{C}$ NMR spectrum of these alkaloids showed characteristic signals at around $\delta 95$ attributed to the $\mathrm{C}-\mathrm{H}$ group attached to two hetero-atoms. The ${ }^{13} \mathrm{C}$ NMR of $\mathbf{2}$ and $\mathbf{3}$ are similar, so that initially they were difficult to distinguish. In the case of $\mathbf{2}$, methine carbon attached to nitrogen appeared at $\delta 87.47$ whereas in 3 the signal is appeared at $\delta 90.27$. In the case of fraction containing compounds 7-9, the ${ }^{13} \mathrm{C}$ NMR spectra showed a signal at $\delta 14.09$ which could be attributed to the methyl groups. It is notable that mass spectrum of the crude fraction containing xestospongin showed distinct peaks at $m / z 447.3458[\mathrm{M}+\mathrm{H}]^{+}$(2), calculated for $\mathrm{C}_{28} \mathrm{H}_{51} \mathrm{~N}_{2} \mathrm{O}_{2}, 447.3950 ; \mathrm{m} / z 463.2311$ $[\mathrm{M}+\mathrm{H}]^{+}(3)$, calculated for $\mathrm{C}_{28} \mathrm{H}_{51} \mathrm{~N}_{2} \mathrm{O}_{4}, 463.3899$; $m / z$ 479.2765 [M+H] ${ }^{+}$(4), calculated for $\mathrm{C}_{28} \mathrm{H}_{51} \mathrm{~N}_{2} \mathrm{O}_{5}$, 479.3848; $m / z$ 495.2682 $[\mathrm{M}+\mathrm{H}]^{+}(\mathbf{5})$ calculated for 495.3797; $\mathrm{m} / \mathrm{z} 511.2176[\mathrm{M}+\mathrm{H}]^{+}(\mathbf{6})$ calculated for $\mathrm{C}_{28} \mathrm{H}_{51} \mathrm{~N}_{2} \mathrm{O}_{6}, 511.3747$. This indicates that the fraction contains several xestospongin alkaloids. Mass spectrum also displayed peaks at $m / z \quad 461.2524[\mathrm{M}+\mathrm{H}]^{+}(7)$ calculated for $\mathrm{C}_{29} \mathrm{H}_{53} \mathrm{~N}_{2} \mathrm{O}_{2}, 461.4107, \mathrm{~m} / z$ 477.2544 $[\mathrm{M}+\mathrm{H}]^{+}(8)$ calculated for $\mathrm{C}_{29} \mathrm{H}_{53} \mathrm{~N}_{2} \mathrm{O}_{3}, 477.4056$, and $m / z$ 493.2458 $[\mathrm{M}+\mathrm{H}]^{+}(\mathbf{9})$ calculated for $\mathrm{C}_{29} \mathrm{H}_{53} \mathrm{~N}_{2} \mathrm{O}_{4}$, 493.4005. The mass of these consecutive alkaloids (2-4) as well as (7-9) differ by 16 mass units corresponding to the substitution of one hydrogen atom with a hydroxyl group $(\mathrm{OH})$ suggesting that alkaloids have a similar skeleton but differ in the number of hydroxyl groups attached to the quinolizidine ring.

The structure of xestospongin-C (2) and xestosponginD were determined by ESIMS, ${ }^{1} \mathrm{H}$ and ${ }^{13} \mathrm{C}$ NMR data. The ${ }^{1} \mathrm{H}$ NMR The ESIMS showed a molecular ion peak at $m / z 447.2391[\mathrm{M}+\mathrm{H}]^{+}$for $\mathbf{2}$ and 463.2311 for $\mathbf{3}$. Fragmentation of $\mathbf{3}$ showed peak at $\mathrm{m} / z 445.2782$ corresponding to loss of water, suggesting the presence of a hydroxyl group in 3 . The ${ }^{1} \mathrm{H}$ NMR spectrum of 3 showed signals at $\delta 4.82,4.42$ and 4.22 assignable to methine and methylene proton adjacent to nitrogen. These data are identical with those in the literature. ${ }^{11}$ The structures of the xestospongin-E (4) was deduced by comparing ${ }^{13} \mathrm{C}$ NMR and mass analysis data with 
those of the known xestospongin-C whose structure was determined by $\mathrm{X}$-ray analysis. ${ }^{12 \mathrm{a}}$ The ${ }^{13} \mathrm{C}$ NMR of the fraction 38-44 revealed the presence of prominent doublet peak at $\delta 98.07$ in addition to the characteristic signals for xestospongin alkaloids. This value is comparable to the $\mathrm{C}-10$ or $\mathrm{C} 10^{\prime}$ of $\mathrm{N}$-oxide xestopongin alkaloids. ${ }^{12 \mathrm{c}}$ Comparison of ${ }^{13} \mathrm{C}$ NMR spectrum and mass analysis data with known $\mathrm{N}$-oxide xestospongin enable us to conclude that the alkaloids present in this fraction were $\mathrm{N}$-oxide xestospongin ( $\mathbf{5}$ and $\mathbf{6}$ ).

Compounds $\mathbf{7}$ and $\mathbf{9}$ were obtained as a mixture along with the known compound $\mathbf{8}$. The structure of the alkaloids was mainly established by mass spectral data. The mass spectrum of the fraction showed peaks at $m / z 461.2524,477.2544$ and 493.2548 , thus deduce the molecular formula of 7-9 as $\mathrm{C}_{29} \mathrm{H}_{52} \mathrm{~N}_{2} \mathrm{O}_{3}$, $\mathrm{C}_{29} \mathrm{H}_{52} \mathrm{~N}_{2} \mathrm{O}_{2}$ and $\mathrm{C}_{29} \mathrm{H}_{52} \mathrm{~N}_{2} \mathrm{O}_{4}$, respectively. The spectroscopic data of compound $\mathbf{8}$ is identical with that of the known xestospongin alkaloid. ${ }^{12 a}$ Molecular mass of $\mathbf{7}$ and $\mathbf{8}$, as well as $\mathbf{8}$ and $\mathbf{9}$, differ by 16 mass units which is equivalent to the substitution of one $\mathrm{H}$ by $\mathrm{OH}$ group. Moreover, since further fragmentation of 9 gives peaks at $m / z 475.2083(\mathrm{M}-18)^{+}$and $457.1984(\mathrm{M}-36)^{+}$ equivalent to successive loss of two water molecules, suggesting the presence of two hydroxyl groups in compound 9 .

\subsection{Antimicrobial activities of the compounds}

The antimicrobial activities of compounds $\mathbf{1}-\mathbf{3}$ were tested using disk diffusion assays. ${ }^{19}$ A moderate to high activities was observed against Escherichia coli and Staphyloccus aureus. Compounds $\mathbf{2}$ and $\mathbf{3}$ were also found to be active against other pathogens such as Rhodotorula, Cryptococcus neoformans, Aspergillus funigatus, Rhodotorula, Candida albicans and Aspergillus niger. The gram positive bacteria penicillin or streptomycin was used for bacteria test while Nystatin was employed for fungus test.

\section{Conclusion}

This paper describes the isolation of bisquinolizidine alkaloid, petrosin and bis-1-oxaquinolizidine, xestospongins from the ethyl acetate extract of the sponge Oceanapia sp., collected from the southern coast of India. Petrosin, xestospongin-C and xestospongin-D were characterized with the help of NMR and mass spectroscopic data while the structure of xestospongin-E, F, G, H, I and J were estab- lished mainly by MS/MS analysis data and comparison of their ${ }^{13} \mathrm{C}$ NMR data with the known and related compounds.

\section{Supplementary materials}

CCDC 716746 contains supplementary crystallographic data for compound $\mathbf{1}$. This data can be obtained free of charge via http://www.ccdc.cam.ac.uk/data request/cif.

\section{Acknowledgements}

We are grateful to the Ministry of Earth Sciences (MoES), India for financial support to carry out this work. We thank Mrs. C Rodrigues for antimicrobial tests.

\section{References}

1. Faulkner D J, Harper M K, Haygood M G, Salomon C E, Schmidt E W 2000 Drugs from the sea N F Basel Karger ed. (Switzerland) 107

2. Blunt J W, Copp B R, Munro M H G, Northcote P T, Prinsep M R 2005 Nat. Prod. Rep. 2215

3. Fujita M, Nakao Y, Matsunaga S, Seiki M, Itoh Y, Yamashita J, Soest R WMV, Fusetani N $2003 \mathrm{~J}$. Am. Chem. Soc. 12515700

4. (a) Takada N, Watanabi R, Suenaga K, Yamada K, Ueda K, Kita M, Umura D 2001 Tetrahedron Lett. 42 5265; (b) Harish S, Carmely S, Kashman Y 1987 Tetrahedron 43 3257; (c) Ichiba T, Scheuer P J, Kelly-Borges M 1993 Helv. Chim. Acta $\mathbf{7 6} 2814$

5. Futsetani N, Li H- Y, Tamura K, Matsunaga S 1993 Tetrahedron 491203

6. Patil A D, Kokke W C, Cochran S, Francis T A, Tomsezek T, Westly J W 1992 J. Nat. Prod. 551170

7. Makarieva T N, Denisenko V A, Stonik V A, Milgram Y M, Rashkes Y V 1989 Tetrahedron Lett. 306581

8. Makarieva T N, Denisenko V A, Dmitrenok P S, Guzii A G, Santalova E A, Stonik V A, MacMillan J B, Molinski T F 2005 Org. Lett. 72897

9. Bensemboun J, Bombarda I, Aknin M, Faure R, Vacelet J, Gaydou E M 2008 Molecules 13772

10. (a) Singh K S, Kaminsky W H, Rodrigues C, Naik C G 2009 J. Chem. Sci. 121 1041; (b) Tilvi S, Rodrigues C, Naik C G, Parameswaran P S, Wahidhulla S 2004 Tetrahedron 6010207

11. Braekman J C, Daloze P, Abreu P M D, Leopardi C P, Germain G, Meerssche M V 1982 Tetrahedron Lett. 23 4277

12. (a) Nakagawa N, Endo M, Tanaka N, Gen-Pei L 1984 Tetrahedron Lett. 25 3227; (b) Pettit G R, Orr B, Herrald D L, Doubek D L, Tackett L, Schmidt J M, Boyd M R, Pettit R K, Hooper J N A 1996 Bioorg. Med. Chem. Lett. 6 1313; (c) Orabi K Y, El Sayed K A, Hamann M T, Dunbar D C, Al-Said M S Higa T, Kelly M 2002 J. Nat. Prod. 651782 
13. Goud T V, Ready N R, Ram T S, Venkateswarlu Y 2003 Biol. Pharm. Bull. 261498

14. (a) Braekman J C Daloze D 1986 Pure Appl. Chem. 58 357; (b) Kobayashi M, Kawazoe K, Kitagawa I 1989 Tetrahedron Lett. 304149

15. Eder C, Schupp P, Proksch P, Wray V, Steube K, Muller E C, Frobenius W, Herderich M, Soest R W M V 1998 J. Nat. Prod. 61301

16. Carroll A R, Ngo A, Quinn R J, Redburn J, Hooper N A J 2005 J. Nat. Prod. 68804

17. Nicholas G M, Newton G L, Fahey R C, Bewley C A 2001 Org. Lett. 31543

18. Boyd K G, Harper M K, Faulkner D J 1995 J. Nat. Prod. 58302

19. Bauer A W, Kirby W M M, Sherris J C, Truck M 1966 Am. J. Clin. Pathol. 45493
20. Bruker 1999: Data reduction software version 5.0, Madison, Wisconsin, USA: Analytical X-ray Instruments Inc.

21. SHELXS-97: Sheldrick G M 1990 Acta Crystallogr. A46 467

22. SHELXL-97: G M Sheldrick Program for the refinement of crystal structures, 1997, University of Göttingen, Germany

23. Farrugia L J 1997 J. Appl. Crystallgr. 30565

24. Bohlmann F 1957 Angew Chem. 69 641; (b) Uskokovic M, Bruderer H, Von Planta C, Willams T, Brossi A 1964 J. Am. Chem. Soc. 86 3364; (c) Crabb T A, Newton R J, Jackson D 1971 Chem. Rev. 71109

25. (a) Scott R W, Epperson J, Heathcock C H 1998 J. Org. Chem. 63 5001; (b) Bladwin J E, Melman A, Lee V, Firkin C R, Whitehead R C 1998 J. Am. Chem. Soc. 120 8559 